\title{
FOUCAULT I TEORIJA SEKSUALNOSTI
}

\section{Željko Senković}

Filozofski fakultet, Sveučilište

Josipa Jurja Strossmayera u Osijeku,

Hrvatska

zsenkovic@ffos.hr

U članku se razmatraju Foucaultovi tekstovi o seksualnosti, nastali u vrijeme kada bujaju ideologije o seksualnom oslobođenju nadahnute W. Reichom i H. Marcuseom, preplavljene psihoanalitičkom teorijom. Svi oni neprestano govore o seksu da bi rekli kako se o seksu ne može pričati jer ga potiskuju buržoaski moral, obiteljski i bračni uzori. Ako nas je Freud od toga oslobodio, to je bilo mlitavo i konformistički. Seks se pretače u diskurs, pa treba propitati govor i oblike naloga tog diskursa. Foucaultova Povijest seksualnosti je povijest tehnika sebstva, genealogija subjekta i modusa prema kojima se subjekt uspostavio $u$ osvit zapadne kulture. Foucault je pokušao odgovoriti otkuda etička briga koja se, ovisno o trenutku, čini značajnijom ili manje značajnom od moralne pažnje koja se poklanja drugim područjima individualnog ili kolektivnog života? Ova njegova opsežna studija centrira se oko genealogije želje, od klasične antike do prvih stoljeća kršćanstva. Pored toga, u članku se komentiraju i religijski stavovi o seksualnosti, koji ne utječu samo na vjernike nego se koriste da primoraju i druge ljude na poštovanje ovih pravila življenja. Oni se uspostavljaju kao "prirodne» istine, formalno odvojene od vjerskih predodžbi koje su ih stvorile.

Ključne riječi: Michel Foucault, seksualnost, moć, čovjek, kultura

\section{Uvodna bilješka}

Istraživanje seksa i seksualnosti sve do prve polovice dvadesetoga stoljeća biloje gotovo sporadično. Platonov Symposion i Schopenhauerova Metafizika spolne ljubavi prvenstveno su tekstovi koji se pitaju o transcendentalnim uvjetima; temat seksualnosti se analogizira i pretumačuje. Mnogo je razloga tome, o čemu se u novije doba naširoko ras- 
pravljalo (Primorac, 2003, 7-8). Zapadnjačka kultura razvijala se pod znakom dualizma duh-tijelo. To je značilo puno toga, a vrlo često bila je to crta bijega od pravih pitanja koja stoje u svezi s urgentnom mogućnosti istinskog i slobodnog življenja. Ideal umnog života u kojemu se, samorazumljivo, događa sublimacija strastvenog dijela u nama, može biti sagledan svakovrsno. Nesumnjivo, to je motivacijski horizont na kojemu je građevina racionalne stege, ali moderna čitanja ljudske psihe su se poodavno odmakla od toga. Od moćne Nietzscheove sjene, pod koju se dobro skloniti kada se želimo maknuti od pada u krhotine »starih vrijednosti«, pa preko J. P. Sartra (Bitak i ništavilo), Mauricea Merleau-Pontya (Fenomenogija percepcije), Simone de Beauvoir (Drugi spol), Bertranda Russella (Brak i moral), otvorilo se novo područje slobode. Liberalna stajališta, feminizam i popularna kultura ovladali su svijetom ideja i nadahnuli tematiku seksualnosti u najširim medijskim krugovima.

U modernom svijetu govorenja o seksu i prikazivanja seksa, djelo Michela Foucaulta Povijest seksualnosti, koje je zasnovalo gledište da društvo konstituira seksualnost, još uvijek stoji kao čarobna svjetiljka što raščarava stari svijet. ${ }^{1}$ Foucaultovi tekstovi o seksualnosti nastaju u vrijeme kada bujaju ideologije o seksualnom oslobođenju nadahnute W. Reichom i H. Marcuseom, preplavljene psihoanalitičkom vulgatom. Svi oni neprestano govore o seksu da bi rekli kako se o seksu ne može pričati jer ga potiskuju buržoaski moral, obiteljski i bračni uzori. Ako nas je Freud od toga oslobodio, to je bilo mlitavo i konformistički, tako da bi trebalo raskrinkati normalizirajuće funkcije same psihoanalize. Foucaulta je puno toga uznemiravalo u sveopćoj buci oko seksa; u diskursu o potlačenosti seksa djeluju i tradicionalne funkcije proroštva.

Povijest seksualnosti je povijest tehnika sebstva, genealogija subjekta i modusa prema kojima se subjekt uspostavio u osvit zapadne kulture. Foucault je pokušao odgovoriti otkuda etička briga koja se, ovisno o trenutku, čini značajnijom ili manje značajnom od moralne pažnje koja se poklanja drugim područjima individualnog ili kolektivnog života? Ova njegova opsežna studija centrira se oko genealogije želje, od klasične antike do prvih stoljeća kršćanstva.

\footnotetext{
${ }^{1}$ Ovaj prolegomenski tekst o Foucaultu posvećujem sjećanju na filozofa Milana Polića. S onu stranu nabrajanja čega se sve ugledni profesor Polić dotakao stoji mogućnost sabiranja oko njegovih temeljnih misaonih i ljudskih dispozicija: slobode i odgoja. U hrvatskom filozofskom kružoku Milan Polić bio je rijetka pojava: odlučan i hrabar govoriti ono na što prisiljava mišljenje.
} 
U dosta svojih djela (uključujući prvi tom Povijesti seksualnosti: Volja za znanjem) Foucault dijalogizira s Marxom, premda više neizričito. Može se uočiti kako u knjizi Nadzirati i kažnjavati upotrebljava marksističku analizu stalnog i promjenjivog kapitala da objasni moderni zatvor kao oruđe disciplinske moći, a akumulaciju ljudi dovodi u vezu s akumulacijom kapitala. U Historiji ludila u doba klasicizma i u Rađanju klinike Foucault izričito povezuje zatvaranje luđaka u azile i siromašnih u prihvatilišta i bolnice s teorijom proizvodnih odnosa i političkom ekonomijom siromaštva: luđaci potrebuju poseban postupak jer su najneproduktivniji dio stanovništva, također bolnica i klinika nastale su iz vrijednosti upotrebe tijela siromašnih.

Načelno govoreći, tražio je slobodu u odnosu na tadašnje prevladavajuće intelektualne tokove. Odbijao je Derridaovu filozofiju: kritizirao je njegovo svođenje diskurzivnih praksi na tekstualne tragove, izbacivanje događaja koji se u njima prepoznaju da bi se zadržale samo oznake jednog čitanja. Derridaovu dekonstrukciju shvaćao je kao restauraciju univerzitetske tradicije i profesorskog univerziteta. S druge strane, na pitanje kada je prestao vjerovati u 'smisao', Foucault kaže da su na njega odlučujući utjecaj imali Levi-Strauss i Lacan, koji su pokazali (jedan za društva, drugi za nesvjesno) da je smisao vjerojatno samo neka vrsta površinskog efekta, odsjaj i pjena, dok nas duboko prožima ono što je bilo prije nas, što nas je podupiralo u vremenu i prostoru, a to je sistem (Eribon, 2014, 215). Ili, drugačije rečeno, postoji neko neodređeno oni, anonimna misao znanja bez subjekta.

Međutim, negirao je da je strukturalist. U svojoj arheologiji ne traži zakone izgradnje, kao što to čine pristalice strukturalističkih metoda, već uvjete njihova postojanja. To ipak nije potpuno uvjerljivo. Naime, ukoliko Foucault u svojoj ontologiji i odbija značaj individualnog, kolektivnog, pa i transcendentalnog subjekta, on utoliko sasvim sigurno ostaje u području holističke i spekulativne filozofije strukturalizma (Milošević, 1980, 89).

Foucault je, prema Richardu Rortyu, bio »vitez autonomije « (Rorty, 1998). Kao i Nietzsche, želio je iznaći svoje sebstvo, ali nikoga nije poticao da se i sam poduhvati tog napora. Nije smatrao da ljudska bića, općenito uzevši, imaju moralnu dužnost biti bodlerovski ili ničeanski izumitelji sebstva. Poput dobra liberala, bio je spreman ostaviti ih da budu onoliko samoinventivni ili banalni koliko ih je volja. Istaknuo je niz opasnosti za demokratska društva. Ukazivao je na tendenciju i 
modele zbog kojih treba biti na oprezu. Međutim, liberalni reformisti smatraju da je Foucaultovo djelo prožeto paralizirajućom dvosmislenošću između značenja moći kao pejorativnog i neutralnog, deskriptivnog pojma. To vodi ka sumnji da je istodobno pokušao raditi dvije stvari. Trudio se služiti ljudskoj slobodi (makar je shvaćao samo kao puku, površinsku pjenu na strukturama, koje su nam u pravilu neprozirne), ali se također, u interesu osobne autonomije, trsio biti bezličan, neukorijenjeni, beskućni stranac spram ljudskosti i povijesti. Ili, drugačije rečeno, želio je pomoći ljudima istodobno iznalazeći sebstvo koje je imalo malo veze s njihovim dispozitivima (Paić, 2011).

\section{Seksualnost kao »volja za znanjem«}

Kada razmatramo Foucaultovo istraživanje seksualnosti tada se ne može zaobići pomisao do koje su došli njemu bliski ljudi i istraživači: gotovo je bilo nužno da seksualnost dobije središnje mjesto u njegovom djelu, s obzirom da je seksualnost bila centralna i u njegovom životu (Eribon, 2014, 47).

Prvi tom Povijesti seksualnosti: Volja za znanjem vjerojatno je najvažniji. U njemu Michel Foucault početak represije smješta u 17. stoljeće, kada ga je nakon nekoliko stotina godina svježine i iskrenosti postalo teže imenovati. Naime, da bi se njime zbiljski vladalo, seks je najprije sveden na razinu jezika, a potom je nastupila kontrola izraza i pročišćavanje rječnika. Tako, nakon Tridentskog koncila, svećenici u ispovijedi više ne traže detaljan opis seksualnih čina kao što se običavalo tijekom Srednjega vijeka. Sada se preporučuje diskrecija i na tome se sve više ustrajava. Još se uvijek traži da se na ispovijedi sve kaže, ali sada više ne koristeći termine koji eksplicitno označavaju seks i seksualnost već u vidu pojma pûti i drugih termina koji zakrivaju sramnu riječ i sramne čine. Teži se k tome da se pût učini izvorom svih grijeha, a seks je zakriven jezikom i više ne biva imenovan. Tu se zapravo očituje osobita ekonomija ograničavanja koja se sjedinjuje s politikom jezika.

Seks je na samome početku razvoja kapitalizma pod tako strogom kontrolom jer je nespojiv s radom; radna se snaga nije smjela raspršivati na užitke. Od 17. stoljeća čini nam se da seksualnost postaje zatočenom, o seksu se šuti, a jedino legitimno mjesto izražavanja seksualnosti postala je roditeljska soba. Bračni par nameće svoj zakon i postaje jedina odobrena forma izražavanja i prakticiranja seksa koji je 
upravljen isključivo prema rađanju. A ono što nije upravljano rađanju i što rađanjem nije preoblikovano, nema više vjere ni zakona. Tako se, primjerice, za djecu »znalo« da nemaju spola, što je bio razlog da im se zabrani da o njemu govore te da odrasli ne vide njihovu spolnost kad god se ona pojavi. Upravo je to ono što karakterizira ovakvu represiju i razlikuje je od zabrana kaznenog zakona. Ta represija funkcionira kao osuda na nestanak, ali i kao zapovijest da se šuti, potvrda nepostojanja pa, prema tome, i kao zaključak da se nema što reći, vidjeti i spoznati.

S obzirom na proizvođenje (ne)istine o seksu, Foucault uviđa da se tijekom 19. stoljeća seks upisuje u dva različita registra znanja, a to su biologija reprodukcije i medicina seksualnosti. Medicina je svoj oslonac pronalazila u biologiji. Odnosno, sva su se medicinska istraživanja, osuđivanja i zatvaranja određenih oblika seksualnosti opravdavala biološkom prokreativnom uređenošću naše vrste. No, postojala je ipak jedna razlika koja je uvelike razdvajala biologiju od medicine, što će se najbolje pojasniti upravo Foucaultovim riječima: $» j e d n a$ se izdizala iz goleme volje za znanjem koja je podupirala znanstveni diskurs na Zapadu; druga je pak proizašla iz tvrdoglave volje za neznanjem« (Foucault, 1994, 40). Iz toga se nadaje vrlo bitnim da je seks osim pitanja dopuštenoga/nedopuštenoga postao i pitanjem istinitoga/lažnoga. Postalo je važnim određenje istine seksa, a kako se do te istine nije moglo doći, ona se proizvodila. Uspostavljeni su aparati za proizvođenje istine seksa. Gledano kroz povijest, postoje zapravo dva velika postupka proizvodnje istine o seksu. Jedan je svojstven civilizacijama poput kineske, indijske, japanske, arapsko-muslimanske i rimske, a poznat je pod imenom ars erotica. Drugi je svojstven našoj civilizaciji i znatno se razlikuje od prvoga, a naziva se scientia sexualis.

Ars erotica istinu izlučuje iz samog užitka koji se uzima u obzir isključivo u odnosu na samoga sebe, a ne u odnosu na neki apsolutni zakon dopuštenog i zabranjenog niti po principu korisnosti. Užitak treba upoznati kao užitak, s obzirom na njegovu pojavnost, na njegovo trajanje, na manifestaciju u tijelu i duši, te na utjecaj koji ima na svakoga pojedinoga čovjeka kao onoga koji taj užitak osjeća. Znanje o toj istini mora ostati tajno, isključivo zbog očuvanja veličanstvenosti i posebnosti, nikako zbog srama i straha od otkrivanja javnosti. Iznimno je važan odnos prema učitelju koji je nositelj tajni i koji jedini može prenositi to znanje. Tako se zapravo čuva djelotvornost $i$ vrlina koju takvo znanje nosi. To uzvišeno umijeće zapravo omogućuje preoblikovanje onoga koji ga ima u smislu potpunog gospodarenja tijelom, omoguća- 
vanja dugovječnosti, bijega od smrti. Scientia sexualis pak označava procedure koje je naša civilizacija razvila kako bi proizvodila istinu o seksu. Te se procedure suprotstavljaju uzvišenom umijeću i tajnama poznatim u ars erotici: riječ je o priznanju. Priznanje je osnovni mehanizam proizvođenja istine. Još je od Srednjega vijeka poznat nalog za ispovijedanjem/priznanjem istine koja će osloboditi duh. Samo se značenje riječi tijekom vremena promijenilo. Prvotno značenje označavalo je naše odobravanje i potvrđivanje statusa i vrijednosti koje pripisujemo nekome drugome, a kasnije se to mijenja u ispovijed, odnosno priznanje vlastitih djela. Priznanje je postalo najcjenjenijom tehnikom proizvodnje istine. Ono je često bilo prisilno, nismo birali priznavati, već smo na to bili prisiljeni. Čovjek je postao »životinja koja priznaje« (Foucault, 1994, 39-51).

Foucault u Volji za znanjem na vrlo inovativan način progovara o nekadašnjim zabranama rodoskvrnuća te o kontroli nad seksualnošću djece. Čini se da se u oba slučaja radi o želji za odstranjenjem, no nakon pobližeg razmatranja biva jasno da je riječ o specifičnim mehanizmima moći i taktikama. Tako se u zabrani rodoskvrnuća ono želi umanjiti odnosno ukinuti, a u kontroli seksualnosti djece ta se seksualnost zapravo proširuje, a s njom i moć koja tu djeluje. Tu analizira i promjenu odnosa prema sodomistu i homoseksualcu, koji se dogodio u 19. stoljeću. Sodomist se kazneno goni i osuđuje, a homoseksualac postaje osobom. O njegovoj se seksualnosti počinje govoriti kao o nečemu što prožima čitavu njegovu osobu. Na taj se način zapravo postiže da se seksualnost uvrsti u svakoga pojedinca, da se svi njezini oblici razvrstaju i podijele u različite skupine te se tako proučavaju, ponovno umnažajući diskurs seksa. Foucault je zapravo pretpostavio da je homoseksualnost proizvod kulture. To nije nešto urođeno, nego je to posebna kulturna kategorija. $^{2}$

»Volja za znanjem će pokazati, uzevši seksualnost kao povlašten slučaj: kako u seksualnu represiju koja se javlja u jeziku možemo povjerovati ako se držimo riječi i rečenica; ali ne možemo izdvojiti dominantne iskaze, a posebno

\footnotetext{
${ }^{2}$ Nasuprot svim glasnim i tihim homofobima u vrsti homo sapiens sapiens treba reći da je homoseksualno ponašanje zabilježeno kod više od 450 životinjskih vrsta. Toliko o prirodnosti i neprirodnosti. Za neke je naprosto zanimljivo, a za druge vrlo uznemirujuće da u mnogim životinjskim vrstama ne biraju s kim se i kako seksati. Činjenica je pak da postoje čak i dugotrajne životinjske homo-zajednice. Na primjer, dva mužjaka crnog labuda zajedno su napravili gnijezdo, brinuli se za ukradeno jaje i uzgojili lijepog, zdravog mladog labuda. On, vjerojatno, nije imao homoseksualnu orijentaciju.
} 
činove priznanja koji se prakticiraju u crkvi, školi ili bolnici a koji istovremeno traže stvarnost seksa $\mathrm{i}$ istinu u seksu; tako represija i ideologija ne objašnjavaju ništa, već uvijek pretpostavljaju određen raspored stvari ili određeno nastrojenje u kojem djeluju, a ne obrnuto. Foucaultu je poznato sve o represiji i ideologiji; samo, kao što je Nietzsche već uvidio, represija i ideologija ne predstavljaju borbu sila, već su samo prašina koju je ta borba podigla.« (Deleuze, 1989, 34)

Deleuzeova interpretacija Foucaultove teorije seksualnosti na nekoliko mjesta se čini vrlo bliskom njegovoj interpretaciji Nietzschea (Nietzsche i filozofija), već i zbog učestalog govorenja o odnosu sila (njem. Kraft) koje čine moć. Naime, postoji nastajanje sila koje je paralelno s povijesti. Riječ je o »silama konačnosti« koje nisu prvenstveno ljudske, nego ulaze u odnos s čovjekovim silama da ga spuste na njegovu konačnost (Deleuze, 1989, 92). Praksa moći ne može se svesti na praksu znanja, oni su po prirodi različiti, heterogeni, uzajamno se pretpostavljaju i preklapaju, ali nesvodivi su. Zbog odnosa moći i znanja, Foucault u stvari govori o mikrofizici. Mikrofizika u njegovoj interpretaciji nije minijaturizacija nama vidljivih formi, nego drugačija dimenzija, novi tip odnosa, pokretan i nelokaliziran.

U Volji za znanjem seksualnost je zapravo »seksualnost «, nije prirodna danost nego ime koje možemo dati jednom povijesnom dispozitivu; on se pojavio gotovo istovremeno s dispozitivom čovjek (Riječi $i$ stvari). U tom smislu, seksualnost je izvorno buržoaska, a javlja se sredinom 18. stoljeća. Karakteristično za to djelo je i napad na psihoanalizu: ona je pojava u jednom povijesnom pregibu čiju arheologiju treba obaviti kako bismo ga se oslobodili. Međutim, Foucault ne kaže jednostavno da je psihoanaliza zastarjela, premda je njena smrtnost gotovo zajamčena. U svoje istraživanje seksualnosti umeće sve dotadašnje istraživačke momente. Sa svih strana pojavljuju se znanja, prakse, institucije, ponašanja, različiti heterogeni elementi koji su obuhvaćeni terminom: dispozitiv seksualnosti.

Freud i psihoanaliza su preko fenomena histerije, kojega Foucault reinterpretira kao fenomen samo-nerazumijevanja, otvorili put razmatranja nerazumijevanja vlastite želje ili vlastite seksualnosti. Na početku, dakle, stoji da subjekt ne razumije vlastitu želju. Pored ovoga, postoji fenomen koji je gotovo inverzija navedenoga: to je prekomjerno, napuhano znanje o seksualnosti, istodobno intenzivno i ekstenzivno, ne samo na individualnom nego i na kulturnom, društvenom i teorijskom području. Zapadnjačka kultura pod jakim je impulsom hiper-razvitka 
diskursa seksualnosti, znanosti o seksualnosti. Oba ta fenomena, nerazumijevanje seksualnosti i mnogovrsni diskurs o seksualnosti, nisu protuslovni. Oni koegzistiraju na Zapadu i jedan od naših problema je da postoji analitička i diskurzivna produkcija znanja o seksualnosti te istodobno subjektovo nerazumijevanje vlastite seksualnosti.

Zašto smo mi Europljani stoljećima željeli znati istinu o našoj spolnosti, umjesto da smo intenzivirali užitak? Za odgovor na to trebalo je poduzeti ispitivanje povijesti seksualnosti. Uobičajena shema je sljedeća: u grčkoj i rimskoj antici seksualnost nije bila gušena. U kršćanstvu se nijekalo i zabranjivalo, što je vodilo šutnji o seksualnosti. Odbacivanje tog pristupa događa se tek s Freudom. Prema Foucaultu, ta je shema neprecizna i neodrživa. Primjerice, radovi Paula Veyna pokazuju da su mnoga pravila moralnog ponašanja, kakva pronalazimo u kršćanstvu, u velikoj mjeri stoičkog podrijetla, podržavana društvenim i ideološkim strukturama Rimskog Carstva. Dakle, to da se netko ženi i ostaje pokraj žene, da spava s njom i ima djecu, da se što je više moguće oslobađa tiranije seksualne želje, bila je tekovina stanovnika Rimskog Carstva, neovisno o kršćanstvu. Poligamija, izvanbračni užitak, uzdizanje užitka, ravnodušnost spram prokreacije, izgubili su se iz rimskog svijeta prije kršćanstva i postojala je samo mala elita, posve mali sloj, društvena kasta privilegiranih i bogatih, koji su se odavali razuzdanosti i nisu se osvrtali na ta načela.

Kršćanstvo je, naravno, bitno. Međutim, ono nije donijelo nove zabrane, nego tehnike za nametanje morala ili mnoštvo mehanizama moći kako bi ulili nove moralne imperative. Dakle, s kršćanstvom ne dolaze nove moralne predodžbe i etičke zabrane nego drugačiji mehanizmi moći. Foucault moć koju uvodi kršćanstvo naziva pastirskom. Stvorena je kategorija pojedinaca koji u kršćanskom društvu igraju ulogu moralnog čuvara stada, pastira u odnosu na ljude-ovce. Ta vrsta ovisnosti važan je fenomen. U rimskoj ili grčkoj antici nitko nije imao ideju da određeni pojedinci spram drugih ljudi igraju ulogu čuvara stada $i$ da ih mogu voditi čitav život, od rođenja do smrti. Političari ili svećenici nikada se u grčkoj ili rimskoj književnosti nisu opisivali kao čuvari stada. Tu predodžbu nalazimo u svijetu istočnog Sredozemlja, u Egiptu, Mezopotamiji i Asiriji. Nalazimo je i u židovskom društvu gdje je motiv stada i čuvara temeljni religiozni, politički i društveni motiv. Bog Jahve je čuvar stada svojega. David postaje pastir. U kršćanstvu su stvari tako postavljene da nema spasenja mimo pastira te se pastiru 
duguje poslušnost. Kršćanska poniznost je interiorizirani oblik te poslušnosti. Nadalje, kršćanski pastir pomoću tehnika ispovijedi otkriva unutrašnjost. Događa se produkcija istine koja se istovremeno razvija s vođenjem savjesti, s vođenjem duša, a konstituira neprestanu svezu između čuvara pastira i njegova stada. Ovo je uključivalo kontroliranje seksualnosti, kao i ovladavanje civilnim društvom, upravljanje iznutra.

Kršćanstvo je etabliralo umjereni moral između askeze i civilnog društva; taj se moral provodio uz pomoć čitavog aparata pastirske, duhovničke službe, čiji se bitni dijelovi dotiču kako vanjskog tako i unutarnjeg znanja. Tako, prema Foucaultu, kršćanstvo doprinosi povijesti seksualnosti u tehnikama interiorizacije, samousmjeravanju pozornosti na ono što se tiče osobne slabosti, vlastitog tijela, tjelesnosti. Kršćanska pût (tjelesnost) je seksualnost viđena u unutrašnjosti subjektivnosti, u podčinjavanju pojedinca sebi samome, što je primarna posljedica uvođenja pastirske moći u rimsko društvo.

\section{Seksualnost kao »tehnika sebstva»}

S drugim i trećim tomom Povijesti seksualnosti Foucault je iznenadio gotovo sve one koji su bili oduševljeni prvim tomom ove studije. Nakon Volje za znanjem slijedi nedoumica, aporija u koju je autora doveo sam pojam moći. Pokušao je otkrivati novi put (vladanje sobom, tehnike sebstva), koji se i prije nazirao. Moć prolazi preko točaka koje su uvijek znak djelovanja sile, akcije ili reakcije neke sile u odnosu na druge sile. Budući da prema Grcima jedino slobodni ljudi mogu vladati sobom, uočeno je da je vladanje drugima povezano s prethodnim zahtjevom za vladanjem sobom. Odnos s drugima se udvaja odnosom prema sebi. Naravno, odnos prema sebi Grci su ukomponirali i udvojili u seksualnosti. To je isprepleteno. No, to se zapravo ne tiče tek ovog ili onog slobodnog čovjeka. Odnos prema sebi zahvaćen je odnosima moći i odnosima znanja. Iz njih je izveden i u njih se integrira. $\mathrm{K}$ tome, odnos spram sebe kao put subjektivacije neprestano se izgrađuje i preobražava, tako da je grčki put pluskvamperfekt. Uvijek iznova, neprekidno se rađaju novi putovi.

Platon je Sokrata u Obrani Sokratovoj prikazao kao učitelja brige o sebi. Sokrat u navedenom dijalogu govori kako Zeus od njega želi da poučava ljude kako se brinuti o sebi, a ne o blagu ili o časti. Takvo se učenje u filozofiji proširilo i postalo jednim od osnovnih oblika istin- 
skog njegovanja samoga sebe, odnosno postalo je središte onoga što se naziva umijećem/umjetnošću življenja. Antički su filozofi imali stav da se svi ljudi moraju brinuti o sebi, za to nikada nije prerano niti prekasno. Po tome što imamo razum razlikujemo se od drugih živih bića, a po tome što razum koristimo kako bismo se brinuli o sebi, ispunjavamo našu osnovnu zadaću.

U antici su briga o tijelu i briga o duši bile povezane. Stoga se smatralo da se medicina i filozofija zapravo bave istim područjem. Pronalazi se analogija, ne samo izraza nego i postupaka koje medicina koristi za izlječenje tjelesnih bolesti i onih koje koristi filozofija za brigu o duševnim stanjima ljudi. Sam pojam liječenja, koji je prije svega medicinski pojam, ali je u upotrebi i u filozofiji, dokazuje da su dvije znanosti isprepletene. Primjerice, Epiktet je učenicima govorio da njegovu školu ne shvaćaju samo kao instituciju u kojoj mogu steći određena znanja koja će im pomoći u životu nego da u toj školi vide i lječilište za dušu. Tadašnjim misliocima bilo je važno da ljudi osvijeste činjenicu da su nesavršeni, bolesni i da im je potrebna pomoć.

U vježbanju (askesis) brige o sebi koristile su se različite metode i postupci. Epikurejci i stoici koristili su metodu iskušavanja koja je služila tome da se čovjek vježba u nekoj vrlini i pokaže koliko je napredovao. Ta su iskušavanja prije svega služila redukciji potreba: naučiti živjeti bez stvari koje nisu nužne. Tako se uspostavlja vlast nad samim sobom, da ne bi ovisili o prisustvu ili odsustvu određenih stvari (pragmata). ${ }^{3}$

Različite vježbe življenja uključivale su i brigu o sebi na području spolnosti. Preporučivala se umjerenost i vladanje sobom, no takva uputstva bila su daleko od kasnijih zabrana i povezivanja seksa sa zlom, kao u kršćanstvu. Antička erotologija imala je namjeru uputiti čovjeka u etiku i estetiku spolnih odnosa, u načine samokontrole.

Vrlo je zanimljiv termin chresis aphrodisia. On kod starih Grka označava upotrebu ljubavnih užitaka. To ne podrazumijeva propisivanje strogih pravila dopuštenoga i nedopuštenoga, već prakticiranje

\footnotetext{
${ }^{3}$ Stoici su brinuli o življenju na način da je to bila »sudska drama u malom«: Što si danas učinio? U kojemu smislu si bolji nego jučer? itd. Međutim, subjekt nije tek sudac sebi samome, nego je kontrolor koji revidira i vrednuje primjenu počela u svome djelovanju. $\mathrm{Ne}$ treba se okrivljavati, nego aktivirati racionalna sredstva za kontinuiranim samo-popravljanjem. Ujedno, ta etika kontrole otvara prostor za novo vrednovanje čovjekove psyche te je ujedno okretanje od »vanjskog« svijeta. Okreneš li se sebi, briga oko onoga što je bilo i što će tek biti na neki način nestaje. I u tome je »umjetnost življenja«.
} 
promišljanja i planiranja, razumnog korištenja ljubavnih užitaka. Pri tome osobito treba voditi računa o tri strategije: potreba, trenutak i položaj. Strategija potrebe shvaća prirodnost ljubavne žudnje koju treba zadovoljiti. Filozofi u staroj Grčkoj naučavali su da je žudnja prirodan osjećaj i da je sasvim normalno zadovoljiti ga. No, nije dobro i potrebno izazivati nasladu jer to dovodi do neumjerenosti. Sophrosyne, stanje koje čovjek teži dostići samosvladavanjem i uzdržavanjem, određuje se kao sloboda. Suzdržavanje od naslada i vježbanje u ovladavanju samim sobom i svojim žudnjama nema za cilj vratiti ili očuvati čednost čovjeka, već mu osigurati slobodu. Sloboda u stoičkom mišljenju ponajprije je sloboda u unutarduševnoj dispoziciji, u smislu kontrole požudnog dijela sebe. Biti neslobodan nije značilo tek biti podređen sili seksualnosti, nego robovati. Na tragu toga, Foucault je rekao:

》Ono što me čudi, to je što u našoj kulturi umjetnost ima veze još samo $s$ predmetima, a ne s pojedincima ili životom [...] Zar život svakog pojedinca ne bi mogao biti umjetničko djelo?« (Eribon, 2014, 415)

Zadnji tomovi Povijesti seksualnosti (Briga za sebe, Upotreba zadovoljstava) nisu nikakav pad u Foucaultovoj teoriji. Oni su doprinos mogućem trgnuću iz »antropološkog sna« (Foucault, 2002, 366-369) i micanju od svih oblika susretljivosti prema sebi, nastale iz brige o sebi, oslobađanju granica inherentnih iluziji o mišljenju bez povijesnih granica, o mišljenju bez nemišljenog. Viđenje koje nas treba voditi je praksa. Za Foucaulta je to: politička praksa. S njom se pak dovodi na čistinu skrivena moć, prokazuju se mjesta poretka gdje je ona skrivena, prihvaćena kao nešto uobičajeno i samorazumljivo.

»Michel Foucault je intelektualnu aktivnost pojmio kao izrazito politički oblik političkog poduhvata oslobođenja: politika istine koja je funkcija svojstvena intelektualcu ostvaruje se u radu na otkrivanju i objavljivanju istine politike. To jest ono što od želje (izopačene) za znanjem istine o moći pravi tvrdokornog protivnika želje za moć.« (Eribon, 2014, 452)

Ono što Foucault zapravo čini u drugom i trećem tomu Povijesti seksualnosti jest pomicanje granica svoje arheologije: za istraživanje seksualnosti treba se vratiti u ranija vremena, do kršćanske prakse pokajanja, ispita savjesti i duhovnog vodstva, pa sve do Grka i Rimljana. Na neki način, nadilazi postavljene granice iz prvog toma Povijesti seksualnosti: Volja za znanjem. Možda je trebao otići puno dalje u povijest i druge svjetove. Premda je konstatirao specifičnost istočnjačke ars erotica, nema preciznijeg zanimanja za Indiju. K tome, Freuda je 
primjerice fascinirao Egipat, a vrlo vjerojatno se korijeni diskursa o seksualnosti mogu pronaći i ondje. No, pored mogućnosti otvaranja novih topoloških istraživanja, važno je uočiti da u nastavcima Povijesti seksualnosti pojam moći ustupa mjesto pojmu subjekta (Gary, 2003).

»Naravno da je pojam subjekta prisutan u Volji za znanjem, ali samo kao incident, a i moć je prisutna u Upotrebi ljubavnih zadovoljstava i Staranju o sebi, ali u interioriziranom obliku, u samoj nutrini rada sebstva na sebstvu. U uvodu u Upotrebi ljubavnih zadovoljstava nedvosmisleno se radi o širenju istraživanja s onu stranu seksualnosti subjekata, na konstituiranje sebstva kao subjekta.« (Miller, 2005, 166)

\section{Dodatak: Religija i seksualnost}

U foucaultovskoj optici, religija je vrlo važna u procesu nadzora i kontrole u području seksualnosti. Stoga ćemo ovdje pridodati nekoliko teza o religijskom odnosu spram seksualnosti. Naime, dok kršćanstvo i budizam u svom izvornom obliku ističu ideal apsolutne seksualne suzdržljivosti kao nečega što vjernika automatski dovodi bliže konačnom savršenom stanju, hinduizam, judaizam i islam imaju suprotno shvaćanje. Svaki svećenik, redovnik ili redovnica podsjetnik su na kršćanske i budističke predodžbe o tome da je seks za ove religije (ili: za prevladavajuća svećenička stajališta) na značajno nižoj razini od suzdržavanja.

Sve zabrane homoseksualnosti direktno ili indirektno proistječu iz religije pa je očekivano i da je otpor prema legalizaciji često religiozne prirode. Vjernici raznih religija staju u obranu svojih vjerskih uvjerenja koja se odražavaju u zakonu. Nakon što je homoseksualnost u europskim državama dekriminalizirana, različite crkvene zajednice istaknule su se otporom spram toga. Razlozi su uvijek bili isti: nenormalnost $i$ neprirodnost, pa stoga: bezbožnost (Endsjø, 2010, 226).

Što reći: kršćanski Bog se ne seksa, dok snošaj Šive i Parvati traje vječno i toliko je intenzivan da se sav kozmos trese. Jasno je da »ima« različitih bogova. Odnosno, predodžba božanskog je i u području seksualnosti paradigmatična za pluralnost $u$ antropomorfičkoj kreaciji transcendentnog regulatora. Istraživači hinduske kulture tvrde da je zapravo teško potpuno točno ustvrditi za ondašnje bogove »tko je s kim《.

Religijsko-seksualna pravila određuju položaj na ovome svijetu te sudbinu poslije smrti. Religijsko-seksualne istine ne utječu samo na vjernike nego se koriste da primoraju i druge ljude na poštivanje ovih pravila življenja. Uspostavljaju se kao »prirodne« istine, formalno od- 
vojene od vjerskih predodžbi koje su ih stvorile. Živimo u društvu u kojemu različite sile neprestano pokušavaju upotrijebiti svoja religijsko-seksualna uvjerenja kako bi utjecali na naše živote; danas srećom manje prisilom (barem u nekim dijelovima svijeta), a više uvjeravanjem (Endsjø, 2010, 360).

Istini za volju, nemoguće je uspostaviti zajedničke norme u ogromnoj raznovrsnosti koja postoji u području seksa i religije. Za ono što jedna religija slavi kao sveti seks, druga religija će propisati smrtnu kaznu; određene vrste institucionalnog seksa neki smatraju središnjim dijelom religijske slike svijeta, a za druge su to demonski elementi. Stoga ni jedna religija ne može nametnuti vlastite religijsko-seksualne istine, a da to istovremeno ne podrazumijeva vrijeđanje religijsko-seksualnih istina drugih.

Mnogi vjernici i danas teško prihvaćaju načela dobrovoljnosti, pristanka i poštovanja u seksu, jer su njihove religijsko-seksualne predodžbe tako snažne da osjećaju dominantan poriv upravljanja seksualnim životima drugih. Uvijek je riječ o istome - volji za represijom - bilo da se radi o homofobiji, seksualnom rasizmu, kontroli ženske seksualnosti posebnim fizičkim tehnikama, zabrani predbračnog seksa itd. ${ }^{4}$

Svako društvo i svaka religija imaju određena pravila o seksu: od osude do dopuštanja, od jednostranog fokusa na neke oblike seksualnog ponašanja do orijentiranja na granice koje pokazuje širi horizont $u$ kojem se vidi izmeđica u društvenome prostoru koja određuje ono što je prihvaćeno i ono što se određuje. Postoje mitovi o radosnim pustolovima i antropolozima koji su zalutali na neki »rajski otok« oslobođen pravila seksualnosti. Zapravo, tamošnje seksualne veze, zasigurno slobodnije nego u društvima odakle bi takvi putnici došli, ipak su se mogle identificirati kroz različite endogamne i egzogamne obrasce ponašanja.

Ne možemo s izvjesnošću odgovoriti na pitanje je li prije religije bilo seksualnih pravila, kao i jesu li religije od svojih početaka htjele regulirati ljudsku seksualnost. Od kada imamo povijesna svjedočanstva o religiji u njima se mogu pronaći prijedlozi sankcija i osude u vezi seksualnosti. U cjelini uzevši, već prvi komparativni uvid u raznolike religije pokazuje da u svim kulturama postoje zamršene strukture na kojima se

${ }^{4}$ Foucault je imao snažan animozitet spram religije i svećenstva, o njima je govorio s revoltom i antipatijom. Doduše, zen mu se činio nečim potpuno drugačijim pa se nije bojao podsmijeha kada je u redovničkoj odori vježbao meditaciju u japanskom zen samostanu. 
presijecaju religijsko i seksualno. Ne postoji jedinstvena shema iz koje se može iščitati jedinstveni odnos religije spram seksualnosti, odnosno on je premrežen kulturalnim konstrukcijama ograničenja, dopuštenja, nadzora, propagiranja, posvećivanja nekog seksualnog modela. Stoga u ovom horizontu religije možemo shvatiti kao stroj regulacije ljudskog ponašanja. Izgleda da je civilizacija od svojih početaka imala svoje trivijalne psihoanalitičare, proto-regulatore privatnog područja, preko kojeg su regulirana i mnoga važna pitanja javnog područja.

Unutar jedne religijske tradicije uvijek će se naći autora koji oponiraju uvriježenom i prevladavajućem stajalištu. Višeznačnosti su česte i uobičajene, pogotovo iz osnovnog čimbenika: život konkretnih ljudi raznoliko mapira odnos religije i seksa. Isključivi autoritet neke biblijske izreke (primjerice: Isusovo protivljenje razvodu) stoji nasuprot modernoj (više-manje) indiferentnosti spram tog stava. Suvremena kulturalizacija svega progutala je ekskluzivitet institucionalnih religijskih autoriteta pa su religije sve manje u mogućnosti biti ono što su dugo željele biti: strogi kodni, mjerni i regulatorni sustavi.

\section{Literatura}

Deleuze, Gilles (1988), Foucault, Minneapolis: University of Minnesota Press.

[Deleuze, Gilles] Delez, Žil (1989), Fuko, Sremski Karlovci: Izdavačka knjižarnica Zorana Stojanovića.

Dreyfus, Hubert L. i Rabinow, Paul (1983), Michel Foucault: Beyond Structuralism and Heremenutics, Chicago: University of Chicago Press.

[Endsjø, Dag Øistein] Endše, Dag Ejstejn (2010), Seks i religija, Beograd: Karpos.

[Eribon, Didier] Eribon, Didije (2014), Mišel Fuko. Biografija, Beograd: Karpos.

Foucault, Michel (1994), Znanje i moć, Zagreb: Nakladni zavod Globus.

Foucault, Michel (2002), Riječi i stvari, Zagreb: Golden Marketing.

Foucault, Michel (2013), Povijest seksualnosti, Zagreb: Domino.

Gutting, Gary (ur.) (2003), The Cambridge Companion to Foucault, Cambridge: Cambridge University Press.

[Miller, Jacques-Alain] Miler, Žak-Alen (2005), »Mišel Fuko i psihoanaliza«, u: Mišel Fuko: 1926-1984-2004: hrestomatija, Novi Sad: Vojvođanska sociološka asocijacija, str. 163-157.

Milošević, Nikola (1980), Filozofija strukturalizma, Beograd: BiGZ. 
Paić, Žarko (2011), Posthumano stanje: kraj čovjeka i mogućnosti druge povijesti, Zagreb: Litteris.

Primorac, Igor (ur.) (2003), Suvremena filozofija seksualnosti, Zagreb: KruZak.

Rorty, Richard (1998), Achieving Our Country: Leftist Thought in Twentieth-Century America, Cambridge: Harvard University Press.

\section{FOUCAULT AND THE THEORY OF SEXUALITY}

\section{Željko Senković}

This article examines Foucault's texts on sexuality, written at a time when ideologies on sexual liberation inspired by $W$. Reich and H. Marcuse were flourishing, rife with psychoanalytical theory. They all constantly speak of sex in order to say that sex cannot be spoken about, as it is repressed by bourgeois morals and family and marital standards. If Freud freed us from this, he did so quite loosely and in a conformist fashion. Sex crosses over into discourse, and so it is necessary to examine the speech and forms of this discourse. Foucault's History of Sexuality is a history of techniques of selfhood, genealogies of subject, and modes according to which the subject was established in the dawn of Western culture. Foucault attempted to discern the source of ethical concern that, depending on the moment, seemed more or less significant from moral attention paid to other areas of individual or collective life. His thorough study centres around the genealogy of desire, from the classical ancient cultures to the first centuries of Christianity. In addition to this, the article also comments on religious opinions on sexuality, which do not only affect the religious, but are also used to force other people to respect those rules of living. They are established as "natural" truths, formally separated from the religious performances that created them.

Key words: Michel Foucault, sexuality, power, man, culture 